\title{
From Exclusive to Common Village: Steeltown, before and after the Collapse of National Steel Corporation, Iligan City, Philippines
}

\author{
Xandelyn Racel B. Reyes, Celyn J. Teatro, Annalou C. Dimantaga, and Froumilyn L. Ochea
}

\begin{abstract}
National Steel Corporation popularly abbreviated as NSC was once the pride of the Philippines for its dream of fully industrializing the country and making it a tiger economy. Organized in 1974, NSC bestowed economic prosperity to Iligan City. NSC's prosperity was the brainchild of the establishment of Steeltown Subdivision in 1987, an exclusive village for NSC employees. With NSC in operation, the village gained prominence in Iligan City. NSC employees manifested distinction from the rest of working class in Iligan City and village created uproar in Iligan City. But in 1995, the sun finally set on NSC, after its privatization, it was start of the troubled years of the company, accompanied with financial problems, mismanagement, and Asian financial crisis, etc., NSC ceased operation in 1999. The closure came as a surprise and brought distress to employees and to Steeltown subdivision. The company's demise was the beginning of social and economic decay of the village. This paper narrates the dramatic transformation of Steeltown Subdivision from being an exclusive to common village. It aims to share moral values and lessons that can be glimpsed out of people's experience involved in the study.
\end{abstract}

Index Terms-Collapse, industrialization, national steel corporation, steeltown subdivision.

\section{INTRODUCTION}

After the harnessing of the energy potentials found in the Agus River, Iligan City from a "sleepy town" in the late fifties begun its booming years. Further development came when Iligan chartered into a City on June 16, 1950 after Pres. Elpidio Quirino signed R.A. No.525. Iligan City then became known as the Industrialize City of the South. The first remarkable step towards industrialization was the construction of Maria Cristina Hydroelectric Plant together with a companion fertilizer plant- Maria Cristina Fertilizer Plant. The fertilizer plant became one of the three big customers of NPC in Iligan. The other two were the government-owned steel mill called National Shipyard and Steel Corporation and the city's electric franchise holder called Iligan Electric Company. [1]

Manuscript received June 7, 2013; revised August 8, 2013. This work is supported by History Department, Mindanao State University-Iligan Institute of Technology, Tibanga, Iligan City, Philippines.

The authors are with the History Department, Mindanao State University- Iligan Institute of Technology, Iligan City, Philippines (e-mail: xandelynracelreyes@y7mail.com).

\section{Methodology}

In dealing with the study, the authors used the qualitative research approach. Authors faced the common problem in dealing with local history studies, the scarcity of written sources. However, in order to strengthen the argument in the paper interview method was heavily employed. Selections of respondents were carefully screened. The large number of informants were former NSC employees and at the same time resident of the village. Residents from Sta. Elena were also interviewed since they were witness of the transformation of Steeltown from being exclusive to common village. Researchers also interviewed residents who, after NSC's collapse were able to acquire house units from the employees. Interviews were recorded and then transcribed. List of respondents are provided in the table below (Table I).

TABLE I: LIST OF INTERVIEWS

\begin{tabular}{|l|l|l|}
\hline Name of Respondents & $\begin{array}{c}\text { Type of } \\
\text { Interview }\end{array}$ & Date of Interview \\
\hline 1.Abalde, Celbert & Personal Interview & November 16, 2009 \\
\hline 2. Alicaway, Ruperto & Personal Interview & January 24, 2010 \\
\hline 3.Balazo, Jesus & Personal Interview & January 24, 2010 \\
\hline 4.Borres, Geneil & Personal Interview & December 22, 2009 \\
\hline 5.Camanan, Calixto & Personal Interview & January 24, 2010 \\
\hline 6.Caye, Macapado & Personal Interview & January 21, 2010 \\
\hline 7.Laguindab, Ali & Personal Interview & January 22, 2010 \\
\hline 8.Mendoza, Kris & Personal Interview & January 19, 2010 \\
\hline 9.Monteron, Eleonor & Personal Interview & January 19, 2010 \\
\hline 10.Montesclaros,ReyLuis & Personal Interview & December 10, 2009 \\
\hline 11.Nietes, Nelson & Personal Interview & November 10, 2009 \\
\hline 12.Pagunsan, Nicholas & Personal Interview & January 20, 2010 \\
\hline 13.Pareno, Odette & Personal Interview & November 16, 2009 \\
\hline 14.Saritado, Medilisa & Personal Interview & January 21, 2010 \\
\hline 15.Sumaylo, Dominico & Personal Interview & December 23, 2009 \\
\hline 16.Tawingan, Pacita & Personal Interview & January 24, 2010 \\
\hline
\end{tabular}

\section{Brief History of NAtional SteEl Corporation}

The abundance of supply of iron scrap after World War II gave birth to the establishment of National Shipyard and Steel Corporation in Iligan City. The company primarily produced steel ingots, billets, reinforcing bars, angular channels, steel shapes and rods. But after supply became scarce the steel bar manufacturing turned into an integrated steel mill, a project assisted by United Nations. Based on studies, Philippines were only second to the Japanese of constructing an integrated steel mill before the Koreans and Taiwanese. [2]

However, the need to purchase US equipment and services led to the negotiations of $\$ 62.3$ million loan 
between NASSCO and Eximbank of Washington DC. In order to comply to the requirement of Eximbank to have a private investor in the Philippines for substantial participation in equity investment, ownership, and policy determination of the steel plant, Pres. Macapagal created a committee to comply to the accorded terms and this resulted to a joint venture in 1961 between NASSCO and Jacinto Steel. The joint venture created the Philippines Integrated Steel Corporation and later renamed as Iligan Integrated Steel Mills, Inc (IISMI). [2]

However, IISMI met cash deficit and began to default its loan obligation granted by the Development Bank of Philippines (DBP) and the Eximbank, the former executed in 1971 an extra-judicial foreclosure proceedings on the mortgages in order for the IISMI to secure its obligation to DBP. IISMI then ceased operation except for its bar mill operations. [2] In order to save the company from DBP's restrictions, IISMI attempted to rescue the foreclosure attempts of DBP by filing a case, the Iligan City lower court executed the write of injunction but immediately after it was lifted, DBP proceeded the foreclosure of IISMI. On February 26, 1974 all the mortgages IISMI plant properties was sold at a public auction to DBP. [2]

The plant facilities of IISMI were operated by National Steel Corporation (NSC) under a contract of lease with DBP. NSC organized by DBP on February 22, 1974 was a wholly-owned subsidiary company. In 1981, DBP sold both the IISMI plant to NSC and all DBP's share holdings in NSC to the National Development Company. Since then NSC became a wholly-owned subsidiary of NDC. [2]

The incorporation of National Steel in 1974 was a milestone in the Philippine economy. It was in the year of the Ox that NSC was born in which according to the Chinese zodiac sign was the symbol of prosperity through fortitude, hard work, and discipline. Years after the National Steel Corporation was born, it had been one of the top corporations in the country and in South East Asia. It was country's $71^{\text {st }}$ largest corporation in 1974 and emerged to $11^{\text {th }}$ top slot, in terms of sales in 1979. [2]

NSC operated the largest industrial manufacturing concern in Northern Mindanao and Iligan City was the heart of it all. NSC had infused a sustained Php 7-8 million payroll for its 3,200 locally-based employees. The company boosted the economy of Iligan City since it was a stimulant to other establishments and industries in the City. [3]

\section{A. NSC Employees}

When progress continued to bless the Company, the employees became the prime beneficiary of it. NSC considered them as the prime asset for the success of the company, stating that the company's success lies on the loyalty and hard-work of the employees. [4] Through bigtime pay checks, incentives and benefits the company was recompensing the hard work of its employees.

The benefits provided by the company to its employees was over and above the requirement of the existing legislation, example of this was the maximum ceiling of P20, 000 per year of hospitalization subsidy to qualified employees. Medical needs were either shouldered or subsidized by the company. These benefits were not only enjoyed by the employees alone, but as a Company policy it was extended to their dependents. [4] Moreover, the company also sponsored activities and departmental excursions. [4]

NSC had given to its employees both the blessings of a basic need and lifestyle, a rare gift that an employee can receive from his employer. The paramount of these benefits was the realization of the dream of the employees of having a village exclusive only for NSC employees.

\section{The Rise of Flourishing Village}

Since NSC employees came from different regions of the country, therefore, some employees were "non-lot and nonhomeowners" in Iligan. [6] Though highly compensated by the Company, some remained leasing an apartment because house planning \& construction hampered their work in the company. They also faced difficulties in building a house i.e. the burden of applying for a housing loan, purchasing the materials and supervising the construction which practically they could not afford to attend, added with the problem of unexpected increase in the cost of materials, it became a deterrent factors for building a house. [7]

The employees dreamt of living in one area where it is exclusive for NSC workers and adjacent to NSC plant. With the realization of the needs of its employees, the Company created a concrete program on land and home ownership. In May 1987, NSC Board of Directors approved the low cost housing project for its employees, a program granting easy and affordable units of houses. The program was known as Mass Housing Project. [9]

Brgy Sta. Elena became the site of the project, the reason was the proximity of the area to the Company; practically it is just 2-kilometers away from the NSC plant. [7]Practicality aside, Sta. Elena was also ideal for residence with a land area of 289.48 hectares it was a place of green pastures and quietude a picture of beauty in nature, it was the perfect environment to relax after long hours of work.

For the housing project, an estimated 37.9 hectares [7] was negotiated by the Company. Areas were bought from landed families in the area such as Padilla, Tucson, Medina, Canoy and Cariaga. Prior to construction the area was coconut and corn fields common crops cultivated in the place. After the ground-breaking ceremony started in February 1988 the operation started, with elevated areas flattened locals of Sta. Elena who resides in the hilly areas can easily come and go. [10]

\section{A. Availment of Housing Units}

In 1988, NSC contracted Kanlaon Construction Inc., for its Mass Housing Project. The residential area was designed in a manner that it reflected a good sound planning. Of its 37.9 hectares, 14.1hectares of it were used for the residential units, 2 hectares were intended for commercial spaces, 2.4 was for open spaces and canals, 5.7 were allotted for streets, alleys, easements, and foot paths, the remaining lands were reserved for future developments and preserved for a natural and cool residential ambiance. [7]

In February 1989, 150 housing units were turned-over to the first batch of subscribers. To no avail, it was not surprising that the subdivision was named Steeltown. In 1990 more housing units were ready for occupation and 
before the end of the same year more or less 500 units were already built. [11]

The full construction was finished in 1992 with a total of 643 housing units but it was not yet fully occupied since the processing the application was extensive, occupants came gradually in the years 1994, '95 and '97. Naturally, the subdivision was integrated to Brgy. Sta. Elena- it comprises Purok 8. The subdivision covered 25 blocks. [12] The cluster of population of Sta.Elena was highly concentrated in Steeltown Subdivision, making it the "heart and center of the Barangay." [13]

\section{A "High Class Village"}

The establishment of Steeltown subdivision in Sta. Elena opened the doors for development in the barangay. Its establishment led to concreting of roads in going to the barangay, water supply, street lights, public vehicles, electricity were met especially to those living in the elevated areas. [10]

Steeltown, in the later part of 1990, started to be labelled as a "high class village", developing an identity of being an exclusive village of rich NSC employees. Gracious living is often associated with the moneyed. Based on the study, the lowest basic salary of an NSC employee was roughly Php $14,000 /$ month and the monthly payroll sums up to Php50 million/month. [14] In an interview with the former NSC supervisor, the lowest salary an employee received a day is Php500.00 and there was salary increase every year and rounded to $10-15 \%$. Aside from monthly salary, there was also mid-year, year-end bonus, $13^{\text {th }}$ month pay, sick leave credits were monetized. Clearly speaking, regular employees were receiving salaries high above the poverty threshold and these benefits were over and above the existing legislation at that time.

It has been known that at the prominence of NSC, employment in the Steel Company guaranteed credit line to most of the business establishments in the City. Tales has been known that an instance such as an NSC employee runs out of cash, he could leave his polo shirt with NSC logo and be allowed to his expenses on charge. [14] Absurd it may seem but in an interview conducted with former employee of NSC the "stories" circulating was true, employment in the Company gained a certain kind of confidence such as leaving their uniforms in times they run out of cash. NSC uniform and ID served as their passport to credit lines, because of Company's stature, business centres such as entertainment places (frequently visited by the employees) or other establishments were confident that the NSC employees will not run back at them. Money poured like rain to NSC employees. The Company provided them almost everything, big time pay checks, hospitalization, summer excursions clothing etc. NSC was one of the best employers in the country.

NSC uniforms were respected and highly regarded. Most of the children in Steeltown were sent to private schools. Intellectually gifted children of NSC employees were given full scholarship by the company. They were admitted to prestigious schools in the country such as UP, San Carlos, De LaSalle, or Ateneo University, etc. in the condition of maintaining good grades. These privileges no doubt made their lives comfortable. This was the chapter of their lives where they lived comfortably and no worries over financial matters.

In those times Steeltown in Iligan City echoed popularity attributed perhaps to NSC and exclusivity of the place. Commonly, people outside the subdivision would refer to steeltowners as rich folks. Residents living nearby Steeltown became a witness to the extravagance of the steeltowners. Vendors and sales agents flocked to the subdivision to sell products. At times fish vendors would take advantage by introducing fishes that usually high in market value. Admittedly, residents in the subdivision were not familiar with fishes that in market standards lesser in price such as tamban (sardine) or galunggong (round scad). A common steeltowners patronizes products that were high in prices.

It was also seldom for steeltowner to ride public jeepneys because they usually hire taxi cab. They were always dressed up and well postured; respondents jokingly recalled that most of the steeltown women would go out with "many layers on their face" because of the thickness of make-up they applied on their faces.

With NSC still in operation, Steeltown had a name in the city, the haven of rich NSC folks. Sta.Elena residents commented that it was a lively village as if every day was a feast there was a competition of noise coming from karaoke, radio components of respective houses of steeltowners. They also remembered how steeltowners celebrated fiesta every first of May. Private vehicles would drove around the village that it was very hard for public jeepneys to pass through. The celebration would be celebrated in advance but would last very long.

They can afford to buy appliances and other things, go on a vacation, regular Sunday family picnic usually at Timoga Swimming Pool, cable and telephone installations, hired house helpers and other extra-amenities in life. Steeltowners clearly experienced a high cost of living; lavishness was experienced since they have the means to afford it. Financial hardships were out of question because they were always aided by the company.

\section{DOWNFALl OF THE TOWN OF STEEL}

There were some factors (accurate and believed) that led to the eventual decline of Steeltown as an exclusive village and the town of rich NSC employees but what is certain was that the collapse of National Steel Corporation was the primary reason for the town to lost its name as a "high class village"

\section{A. God Punished The Town?}

The belief in the law of karma is already embedded in the Filipino culture. People around Steeltown came to maliciously accused that perhaps God punished the town because the people living within had become abusive, arrogant, adulterous, etc. Being an NSC employee could have been a good ground for building a very good relationship. But steeltowners were labelled as "snub" by the local residents like snubbing the community outside the subdivision, ignoring barangay services and possessing the 
attitude of arrogance like treating the people outside the subdivision as if beneath them. Steeltowners sometimes refer to children of non-steeltowners as "badjao"1 everytime they would sneak a look in the house of a steeltowner to watch a $t v$ program, at times they would threw off tamban fish in the canals Competition within steeltowners was also seen cases like having first the telephone or cable connections.

NSC was a stimulant to businesses in Iligan City like Karaoke Bars, Night Bars, etc. Every night these establishments would be filled with men wearing gray uniforms. Making temptation in close hand with the employees, their salary was more than enough to provide their families that is why they had their No.2 (describing their second family/ or mistress.) Often some of them engaged themselves in worthless activities like gambling. Sadly, there were moments that their children's lives were misdirected because they were always or in almost cases, given by their parents with everything they want. Most of the people around Steeltown conceived that it was "gaba" that struck the village (bad karma) because residents were abusive and they were wasteful of things they had. Whether is it karma or punishment it is still a question. But if it is the will of God, perhaps he just wanted some lessons to be learned.

\section{B. Collapse of the Steel Industry}

This factor could perhaps the best attributes to the decline of Steeltown. In its halcyon days, there was no doubt that NSC blessed not only its employees but as well as the City in general. More than providing employment it also stimulated many business centres in Iligan. Big industrial firms also relied on the operation of NSC it includes Refractories Corporation of the Philippines which manufactures industrial bricks for the NSC's furnaces. Not to mention the revenues it directly deposits to the City government, records showed that in 1990s NSC revenue accounted for as high as $75 \%$ of the total tax revenue of the City and 35\% of the City's overall income. In 1998 where operation was still stable, NSC paid about Php 130million in taxes which were $50 \%$ of the total city tax collection. NSC was the biggest taxpayer of the City. [14]

NSC had faced many challenges, there were rough times when it had to face crisis like in the year 1989 when the production did not go very well but it recovered from the storm. But when it finally ended its collapse was catastrophic because it totally upset the economic situation of Iligan City in general and most especially it turned the world up-side down to NSC employees who thought that the sun would never set on the company. When privatization came in 1995 troubled years started and it was the start of the end.

A study conducted provided facts about the closure of NSC and the extent of difficulties it left in the City. Though privatization in 1995 was considered as the prime reason for its closure but the combined internal and external factors led to the collapse.

After the privatization in 1995 the company was bought

${ }^{1}$ Badjao are one of the 13 Moro ethnolinguistic groups in the Philippines. But sadly, the name is often used as a derogatory word by the local mainstream population to refer to grubby person. by Wing Tiek Holdings Bhd. of Malaysia. But when Tiek faced financial troubles it sold NSC to Hottick Investment Ltd., another Malaysian company. Accordingly the management was ineffective because in the first place the Malaysians were steel traders and not steel makers. Liberalization opened the doors for serious competition with other cheap imports from China, Russia and Korea. This crisis was supplemented with another crisis in 1997, when Asian financial crisis hit the country that worsened the financial situation of the company. Its debt ballooned to Php 12 billion, $50 \%$ of it was attributed to peso depreciation. Peso depreciation accompanied by surge in interests rates due to Asian financial crisis. NSC then faced the difficulties servicing its loans. [14]

Poor internal management was also held responsible for its downfall. There was no system of check and balance, internal audits were cut, and bidding \& pricing committee was abolished. To top it there was a suspicion of money laundering and salting. It was reported that financial heavy loss of NSC amounted to Php2.6 billion in 1996, it further increased in 1998 to Php4 billion. Significant decrease came in 1997 and early 1999 it ceased operation. [14, p.18]

One of the most immediate effects of the closure was the loss of employment. About 1,817 regulars workers were displaced the figures does include to other business centres or industries that were dependent on the operation of the company and those who were dependent on the earning capacities of NSC employees. An enormous amount was lost in money circulation of Iligan's economy. NSC's collapse made a general economic slump in the City. The company was the city's biggest taxpayer, with its sudden shut down it caused a great deal of economic distress in the City. [14]

Industries dependent on NSC's operation also shut down like Refractories Corp. others cut down their production and some made a heavy losses when NSC collapse like the National Power Corporation.[14, p.18] Moreover, financial activities in the city temporarily halted immediately after the collapse of NSC.

\section{IMPACT ON STEELTOWN SUBDIVISION}

The news of the collapse startled the steeltowners. Without the company all felt worried of what the future will bring to their children and family. In those days, they felt that a "dark" future awaits them. The collapse left an immense distress for many of them.

Immediately after the collapse, all the benefits they were enjoying were cut -off. Both salary and non-salary benefits they had once enjoyed were seized from them. The sudden cut down of benefits made a great impact on their lives and sometimes it was unbearable especially in cases when their children got sick, they were burdened of finding money for medicine or to go to the doctor for check-ups or for hospital bills unlike before that the company was there to support them.

Evidently there was a dramatic shift in their lifestyle from being "can-affords" they turned into cost cutting strategies in order to survive the storm. Household helpers were terminated, cable subscriptions were cut-off. Others sold their appliances, jewelleries etc., that can aid their financial 
woes. Jesus Belazo recalled that they planted vegetables around their house like camote tops, alugbati (philippine spinach), malunggay (horseradish) and livestock such as chicken were raised on their backyard. As he recalled it was the period wherein eating vegetables became their everday diet. It was also added that it was really difficult times because there were moments that they would just ask for puso ng saging (banana blossom) or malunggay (horseradish) sprouted around Sta.Elena neighbourhood just to have something to eat. It was also the period when they seldom got to taste meat or even fish-if they can afford to buy one it was usually galunggong (round scad) fish and sometimes their children will have it first and they would just settle for vegetables.

Immediately their children were transferred from private to public schools, others temporarily stopped from going to school and some to the extent of finally ceasing from attending schools because of financial distress. The collapse was a dream shuttering for the residents, dreams of sending their children to exclusive schools in Cebu or Manila all flushed away.

Steeltown became quiet after NSC's closure. Sta. Elena residents observed that they could no longer hear loud music coming from the neighbourhood. There was indeed a visible impact in Steeltown after the closure. For instance, the previously extravagant fiesta celebration turned soundless. Before, they could still solicit large amounts from the subdivision but after the closure some did not even celebrated it.

Employment became the primary concern of NSC employees after the closure. Some displaced workers were fortunate to be absorbed in the domestic economy but the tight financial and economic situation of Iligan did not provide a full and effective absorption of displaced workers. [14] Others ventured into small entrepreneurship by building small sari-sari stores in their own house. Those who received their separation pay were able to put up big investments, popular option were restaurants and smallscale livestock farms. Others used their separation pay for their placement fee for employment abroad.

\section{A. Out-Migration}

Evidently, some due to lack of alternative employment in the city decided to seek income opportunities in other places. Earlier it was mentioned that NSC employees are not all from Iligan City, therefore after the crisis hit, they decided to go back to their respective place of origin- in Luzon, Cebu or Cagayan de Oro- and started a new beginnings. A bulk of those who out- migrated from the subdivision sold their units and used the money in starting new ventures. It was the financial woes that pushed them in selling the house because it still has loan liabilities to be filled or else faced the foreclosure. Among those who were able to purchase a unit in the subdivision was Ali Laguindab who bought the house from a former NSC employee named James Alota. He bought it for Php220, 000 which excludes the payment in SSS. The buyer had to pay the remaining debt in SSS. Others decided to lease the unit instead of wholly selling it.

\section{B. From Exclusive to a Common Village}

Soon after the collapsed there was an out-migration in the subdivision and non-NSC employee started to live in the village thereby loosening its name as exclusive village only for NSC employee. These were one of the major changes that immediately occurred in the subdivision after NSC's demise. Prior to the collapse the subdivision was sort of a homogenous village, they are all NSC employees. According to the estimates of the President of the newly established homeowner's association in Steeltown- the Steeltown Subdivision Residence Association Inc., there were 150 units in subdivision whose present occupants are Muslims. There were others who rented the units and others were occupied the unit for free with owner's consent, perhaps, relatives or extended family. The hodgepodge of non-NSC employee transformed the village from being exclusive into just a mere common subdivision.

This change brought discomfort to some original residents of the area. A respondent commented that they felt unsafe anymore unlike before that knew who came in and out in the subdivision because practically faces then were familiar to them since they work in the same place but this time they see unfamiliar faces roaming around subdivision and it gives them a weird and discomfort feeling. Some of the changes were early morning musical tune coming from the Mosque, it was recently established in the village after the occupation of new and non-NSC employees who practiced the religion, Islam. The establishment of Mosque came when a house unit was sold to a Muslim person, when this person died his unit was donated as a prayer facility for his Muslim brothers in the subdivision since he has no family to inherit it.

\section{CONCLUSION}

The history of Steeltown is intertwined with the history of National Steel Corporation because without NSC Steeltown would be non-existent. The success of the company became the prime reason for its establishment and for it to be labelled as a "high class village. But with the collapse of NSC, a major shift came in their lives as well as in the subdivision. When the operation halted it was as if the life in the subdivision had also temporarily ceased. The collapse of the company brought decline in the socio-economic status in the subdivision. When people were busy on how to survive the storm, they, in return neglected their responsibility to the subdivision because they need to find means to survive, to the extent of selling their units and abandoning the village. No preparations were made of such tragedy in their lives. Not even in their wildest imagination that such big company will have its downfall and such downfall will have a domino effect.

It was a "period of prayers" and they managed to pass the stormy period in their lives. But the credit is due to the villagers, if it wasn't for their sheer determination to survive they would not make it. Probably, they could have left Steeltown and the village would have been a "ghost town" today. But as the saying goes life must go on and so they continue their lives facing the reality that NSC is no longer there to support them. The residents who stayed in the village had lived to tell the tale. The story shared to the researchers was intriguing yet inspiring. Steeltown Subdivision continued to exist in spite of NSC's demise. The image of being an exclusive village and town of rich 
NSC employees may have went along to the company's demise but the closure did not hinder them to continue living.

\section{REFERENCES}

[1] G. Salgado. A History of Phenomenal Growth of an Industrial City (1950-1980). [Online]. Available: http://www.iligan.gov.ph/index.php?option=com_content87@Itemid $=612 /$.

[2] NSC News, "National Steel Corporation: A People's Early Vision for a Progressive Country," pp. 1-11, January-February 1986.

[3] NSC News, "NSC and Iligan: The Institution in a City," pp. 3-4, September-October 1984.

[4] NSC News, "Compensation and Benefits," pp. 4-6, August 31, 1986.

[5] NSC News, "Housing program of a better roof," vol. 12, no.8, pp. 6-7, November 30, 1988.

[6] NSC News, "Steeltown," pp. 2-6, vol. 14, February 15, 1989.

[7] M. Rojo, "Iligan mass housing units turned over," NSC News, pp. 23, July 1991.

[8] Pacana and Reguiro, "History of Barangay Sta. Elena," Iligan City (1996-1998), Undergraduate Thesis, Dept. of History, MSU-IIT, Tibanga, Iligan City, Philippines, March 1991.

[9] NSC News, "Turn Over: SSS Chiefs visits Steeltown," pp. 19, vol. 15, no. 8, August 31, 1990.

[10] Barangay documents, Steeltown Subscribers, pp. 1-19.

[11] Barangay Development Plan, Sta.Elena.

[12] L. Basilio and J. Cabasan. (December 2004). Local governance and the challenges of economic distress: The case of Iligan city. [Online]. Available: http: // www. dirp3.pids.gov.ph/ris/dps/pidsdps0445.pdf.

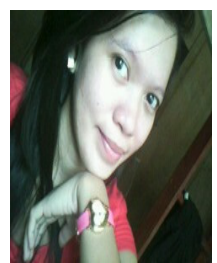

Xandelyn Racel B. Reyes was born in Iligan City, Philippines on June 28, 1990. A graduate with honours of bachelor of arts in history at Mindanao State University-Iligan Institute of Technology, Iligan City, Philippines last April 8, 2010. She is currently enrolled and concentrating in her master's degree in history in the same institution. At present, she is an Instructor of the Department of History of Mindanao
State University-Iligan Institute of Technology. Ms. Xandelyn Racel B. Reyes is currently teaching Philippine History, Life and Works of Rizal, History of the Filipino Muslim and Indigenous Peoples of Mindanao, Sulu and Palawan of the Department of History, MSU-IIT. Research interest is enriching local history studies in Mindanao, Philippines.

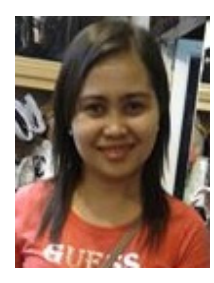

Celyn J. Teatro was born in Initao, Misamis Oriental, Philippines on April 18, 1982. A graduate with honours of bachelor of arts in history at Mindanao State University-Iligan Institute of Technology, Iligan City, Philippines. She earned her master in history degree in the same institute in 2005. She is currently an assistant professor in the Department of History of MSU-Iligan Institute of Technology. Prof. Celyn J. Teatro is currently the instructor of Asian Civilization, Modern South-east Asia, Philippine History, Life and Works of Rizal, and History of the Filipino Muslim and Indigenous Peoples of Mindanao Sulu and Palawan of the Department of History, MSU-IIT, Philippines. Same with other researchers in MSU-IIT, her interest is currently focusing in enriching local history studies in Mindanao, Philippines.

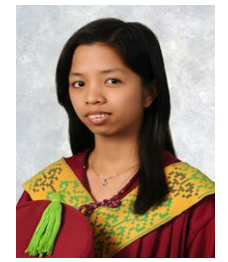

Annalou C. Dimantaga was born in Iligan City, Philippines on August 21, 1988. A graduate of bachelors of arts in history at Mindanao State University-Iligan Institute of Technology, Iligan City, Philippines last April 8, 2010. At present, Ms. Annalou Dimantaga is a licensed Social Science secondary teacher at Liberation Institute, Misamis Occidental, and Philippines. At present she temporarily halted in research in order to concentrate in her teaching career.

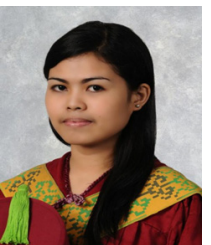

Froumilyn L. Ochea was born in Iligan City, Philippines on April 5, 1990. A graduate of bachelor of arts in history at Mindanao State University-Iligan Institute of Technology, Iligan City, Philippines last April 8, 2010. Ms. Froumilyn Ochea is currently enrolled in Certificate for Teacher's Program in College of Education of the same institution. 